\title{
Application of Peplau's Theory Model to Overcome Intestinal Parasites and Anemia among Schoolchildren
}

\author{
Nehal Allam ${ }^{1,2, *}$ Zeinab Al Orapy ${ }^{1,2}$, Wafa A.AL Megrin ${ }^{2}$ \\ ${ }^{1}$ Faculty of Nursing, Ain Shams University, Egypt \\ ${ }^{2}$ Faculty of Science, Princes Nourah Bint Abdulrahman University, Kingdom of Saudia Arabia, Arabia \\ *Corresponding author: nehall60@yahoo.com
}

\begin{abstract}
Aims: This study monitored the effect of applying therapeutic interactions model based on Peplau's theory on schoolchildren's health status and prevention of intestinal parasite infestation and anemia .We assessed children and parents' knowledge, skills, and adaptive behaviors for dealing with intestinal parasite infestation and anemia. Design. A descriptive quantitative, pre/post-test design was used, with an age and sex-matched control group. Nonprobability, purposive sampling of 600 schoolchildren was recruited from 6 primary schools in East and South Cairo governorate, Egypt. Methods. There were 6 stages of data collection as this more clearly explains the content of this section. I. A pre/post Peplau's theory model questionnaire for structured interviews II. Pre/post application of interpersonal process of therapeutic interaction model assessment format which is based on Peplau's theory and includes 4 phases. III. Observation Checklists (pre/post format). IV. Child/Parent Guidance Booklet. V. Parasitological Examination VI. Blood sample analysis Results. There were highly significant effects of model application on schoolchildren health, and a strong association between prevention and management. Conclusions. The study concluded that prevalence of intestinal parasite infection and anemia between the 2 settings was significant. Following the intervention, child health status was excellent and schoolchildren had a complete understanding of care management.
\end{abstract}

Keywords: intestinal parasites, anemia, Peplau's Theory, schoolchildren, risk factors

Cite This Article: Nehal Allam, Zeinab Al Orapy, and Wafa A.AL Megrin, “Application of Peplau’s Theory Model to Overcome Intestinal Parasites and Anemia among Schoolchildren.” American Journal of Nursing Research, vol. 5, no. 6 (2017): 209-218. doi: 10.12691/ajnr-5-6-3.

\section{Introduction}

Intestinal protozoan infections among the pediatric age group remain a chief worldwide public health challenge, particularly in developing countries. Parasitic diseases are highly endemic, although patchily distributed. Hotez et al, [1] stated that in the Middle East and North Africa, which comprises of 20 countries, there are nearly 400 million people suffered from parasites. In addition [2] mentioned that intestinal parasitic infections are spread worldwide, with the highest frequency and intensity happening in developing countries where more than 1.5 billion people, $24 \%$ of the world's population, are presently infected. Contagions are extensively disseminated in tropical and subtropical areas, with the highest statistics occurring in sub-Saharan Africa, the Americas, China, and East Asia. Over 270 million preschool-age children and over 600 million school-age children live in areas where these parasites are intensively spread, and are in need of treatment and precautionary involvements [3].

Additionally [4] found that Entamoeba coli (in 19.3\% of pupils), Ascaris lumbricoides (3.8\%), Hymenolepiasis nana (12.5\%), Enterobious vermicularis (5.7\%) and Giardia lamblia (12.5\%), were spread with changing proportions between male and female scholars at Minia
Governorate in Egypt. Pullan et al [5] reported that worldwide figures of infection in 2010 were as follows: 439 million people were infected with hookworm, 819 million with Ascaris lumbricoides, and 464 million with Trichuris trichiura. Ramakrishnan et al, [6] reported that intestinal parasites are frequently transmitted by low levels of environmental and personal hygiene, pollution of diet and drinking water and poor sanitary which are existing conditions in developing countries. Proper investigation of the parasitic etiology of diarrhea, leading to prompt and effective management, can help to decrease morbidity and mortality in such patients.

Anemia is a community health problem amongst schoolchildren in developing countries. According to [7] about 400 million schoolchildren are sick; they are physically and academically compromised. The prevalence among schoolchildren ranges from 12- 60\%. Egyptian studies in Al-Fayom Governorate, Al Ghwass et al, [8] found that the frequency of iron deficiency anemia was $64 \%$ among children aged 6 months to 12 years. This is greater than others where the incidence of iron deficiency anemia was $43 \%$ and $55 \%$ among studied samples of schoolchildren in Cairo and El-Minofia, respectively [9].

Parasites are one of the foremost etiologic cause of diarrhea, and are present in $61 \%$ of individuals suffering from diarrhea. In an assessment carried out in the Delta region, $67.1 \%$ of patients with long-lasting diarrhea were 
found to be infected with intestinal parasites. World Health Organization [3] recommends intermittent therapeutic management without preceding human diagnosis for all threatened individuals living in endemic areas. Health and hygiene education can help to reduce transmission and reinfection by reinforcing fit behaviors. Delivery of acceptable hygiene is also important. In 2013, over 368 million schoolchildren, representing $42 \%$ of all schoolchildren at danger, were treated with anthelminthic drugs in endemic countries. Schools deliver a chiefly good entry point for hygienic actions, and they permit for easy establishment of the health behavior and health education, such as encouragement of washing hands and keeping environmental sanitation.

World Health Organization [9] commends usage of albendazole and mebendazole (400 $\mathrm{mg}$ and $500 \mathrm{mg}$ doses, respectively) for deworming. These medicines are effective, cheap, and parents can give it. The universal goal is to eradicate morbidity among children by 2020. It could will be achieved by repeatedly handling at least $75 \%$ of the schoolchildren (an estimated 873 million).

Furthermore, D'antoniop et al, [10] revealed that academics and doctors have documented the significant effect of the mid-twentieth century emphasis on personal relationships and interactions in nursing. As a way onward, we refer to the pivotal ideas of Hildegard Peplau. Pelpau was a pioneer theorist who introduced the middle-range theory of interpersonal relations to promote health care of children. The power of interactions in nursing care used as a back bone in the current study in emphasizing the nurse-schoolchildren relationship. The nurse and child work together to become more knowledgeable in the care process. Peplau's designs, in particular the pivotal Interpersonal Relations in Nursing, can offer a model in clinical practice D'antoniop et al [10]. The relationship between nurses and children lies at the heart of nursing practice.

According to [11] and [12] nursing is therapeutic because it is a healing art, assisting an individual who is sick or in need of health care. Nursing can be viewed as an interpersonal process because it involves interaction between two or more individuals with a common goal. In nursing, this common goal provides the incentive for the therapeutic process in which the nurse and patient respect each other as individuals, both of them learning and growing as a result of the interaction. An individual learns when he or she selects stimuli in the environment and then reacts to these stimuli. Peplau describes this as a "maturing force and an educative instrument" involving communication between two or more persons with a mutual goal. The person learns when he chooses stimulus in the situation and then reacts to it as a feedback .

Moreover Peplau suggested four phases of the therapeutic nurse-patient relationship which can be applied in interactions with schoolchildren who are suffering from intestinal parasites and anemia. (1) Orientation phase: This phase is directed by the nurse and involves engaging the child in treatment, providing explanations and information, and answering questions taking into consideration cultural and educational backgrounds. The nurse helps the child to recognize and understand their condition, and the importance of intervention and treatment [11] and [12]. (2) Identification phase: The nurse and the child work interdependently, express feelings, and begin to feel more confident. (3) Exploitation phase: The child makes full use of the services offered. (4) Resolution phase: The child no longer needs professional services and gives up dependent behavior [11] and [12]. Child health is closely related to Egypt's future. The constant development of medical treatment will greatly improve the spectrum of child diseases that can be treated, and improve disease management in pediatric nursing. Application of Peplau's developmental theory through interpersonal relationships in the nursing process will lead to promotion of pediatric nursing that focuses more on family and child safety, teach the children about health behavior and new nursing trend, and improve use of evidence-based nursing in schools [11] and [12]. The study aimed to monitor the effect of application of Peplau's theory, therapeutic interactions model, on schoolchildren's health status, intestinal parasite infections and anemia prevention through: Assessing the children and their parents' knowledge, skills and adaptive behaviors in dealing with the disease. Providing the children and their parents with essential information and skills to overcome intestinal parasite infections and anemia Evaluating the influence of Peplau's theory model in relation to child health status and disease prevention.

\section{Methods}

\subsection{Design}

A descriptive quantitative, pre/post-test design was used in this study with an age and sex-matched control group to address the following research question: To what extent does the application of Peplau's Theory, therapeutic interactions model, promote schoolchildren's health? Can the application of Peplau's theory, therapeutic interactions model, overcome intestinal parasite infections and anemia? Does supplying children with knowledge, skills, and adaptive behaviors have an impact on dealing with the disease?

\subsection{Setting}

The study was conducted at 6 Primary schools: 3 schools from East Cairo Governorate and 3 schools from South Cairo governorate in Egypt.

\subsection{Subjects}

To select schoolchildren who were representative of the sample, we undertook a nonprobability purposive sampling of 600 schoolchildren and their parents who were recruited to participate in the study. Six hundred forty subjects were initially recruited of which 600 completed the study, and 40 dropped out. Twenty of these subjects who dropped out had developed severe complications, and the other twenty withdrew due to other circumstances. The inclusion criteria were as follows: children aged from 6 to 12 years old with intestinal parasites, who do not suffer from any congenital anomalies or severe complications, and who attend school regularly. 


\subsection{Data Collection}

There were 6 stages of data collection as this more clearly explains the content of this section.

I. A pre/post Peplau's theory model questionnaire for structured interviews: This was developed by the researchers, with consideration of relevant references, to determine children's needs. It was written in a simple Arabic language, and its content validity was assessed and secured by 7 expert consultants from the pediatric nursing and medical departments. The questionnaire included 2 main parts: (1) Included information related to subjects' characteristics - age, sex, duration of disease and disease history of child, and parents' education level and occupation; (2) Concerned with (a) Children and parents' knowledge regarding intestinal parasites - types, life cycle, causes, manifestations, nursing care, treatment phases, and side effects. Also, source of water for drinking, toilet facilities, and hygiene practices. (b) Measures used to overcome different health problems, e.g. anemia, nausea, vomiting, diarrhea, anorexia, trouble falling asleep, fatigue, and abdominal pain. (c) Psychological problems of the child and their parents concerning disease, e.g. anxiety, depression, or frequent feelings of apathy, and the measures used to overcome these problems.

There were 35 questions in total, written in the form of closed- and open-ended question A scoring system was devised for analyzing questionnaire responses. The scoring system for children scores was as follows: $>75$ Very Good, 50-75 Average, and < 50 Poor.

II. Pre/Post an interpersonal process of therapeutic interaction model assessment format: It based on Peplaus Theory 4 phases and includes:

1. Orientation, 2. Identification, 3. Exploitation and 4. Resolution.

The total number of questions was 22, written in the form of closed- and open-ended questions. The scoring system for children's scores was as follows: $>75$ Very Good, 50-75 Average, and < 50 Poor.

III. Observation Checklists (pre/post format): This was designed to assess the children's and parents' performance related to: (1) Measuring axillary temperature (2) Measures to reduce fever (3) Personal hygiene (4) Pain relief.

The total number of procedures was 3.The researchers allocated 10 marks for each procedures performance. The scoring system for children's scores was as follows: $>7$ Very Good, 5 -7 Average, and $<5$ Poor performance.

IV. Child/Parent Guidance Booklet: This was designed to supply the children and their parents with essential information about intestinal parasite infection prevention and measures to overcome the environmental risk factors.

V. Parasitological Examination: The child was requested to give a stool sample in the given specimen bottle after simple instruction on how to put give the stool sample. The researchers ensured obedience. Then collected samples examined, without preservation, in a private laboratory. Opinion was based on the presence of helminth ova and protozoan cysts under microscopic investigation. The stool samples were also analyzed to monitoring progress and treatment stages.

VI: Blood sample analysis: Each enrolled child was asked to give blood sample follow strict sterile technique.
A $3 \mathrm{ml}$ specimen of venous blood was withdrawn into a sample bottle containing ethylenediaminetetraacetic acid (EDTA and gently mixed it with the blood sample to prevent clotting. Subjects were adequately informed about the purpose.

The researchers collected each sample and sent it to a private laboratory. In addition, to monitor the child complete blood picture, the researchers checked each blood sample results to confirm presence of anemia. Anemia was defined as a hemoglobin level of less than $11 \mathrm{~g} / \mathrm{dL}$ and severe anemia was defined as hemoglobin of less than $5 \mathrm{~g} / \mathrm{dL}$, in accordance with [7] recommendations.

\section{Fieldwork}

The study was carried out within 16 months from October2016 to January 2017

Application of Peplau's theory interpersonal relationship model was carried out in 4 phases:

I. Assessment (orientation phase): The researchers collected data over 3 months, interviewing subjects weekly (for 13 weeks) on Wednesdays and Thursdays during school time (8.00 a.m. - 1.00 p.m.). Schoolchildren and their parents were interviewed to determine their perceptions about intestinal parasite infection and its management. Researchers also assessed their basic needs, anxieties, frustrations, and conflicts. The researchers attempted to create trusting relationships with children and tried to understand the various issues facing them at home through the interaction process.

II. Planning Phase (identification phase): After the initial 3 months, the researchers started to work interdependently; the children expressed feelings, and began to feel stronger. Then, more details were collected about children's health statuses using laboratory investigations and child medical records, including weight, height, health problems, treatment phases, and follow up of progress.

III. Implementation (Exploitation phase): It carried out within eight months for the practice solving children problem, providing alternatives based on their needs and interests to make use of the services offered .Forty hours in each school were allocated to cover both the theoretical and practical elements. The theoretical element of the intervention included 4 educational sessions about intestinal parasite types, causes, manifestations, and prevention measures (hygienic measures as hands washing before and after any daily life activities; washing green vegetables and fruits before eating, keep food covered; and keeping fingernails clean and short, in addition to complications and management, and importance of investigations and follow up. The teaching methods used were lectures, group discussions, demonstrations, a comic book, drawing activities and role-play. Instruction media included colored posters, transparencies, handouts and use of the blackboard. The researchers took into consideration the children's levels of understanding, motivation, and reinforcement techniques such as praise in order to enhance learning. Two practical sessions were given to demonstrate the model and the procedures involved, such as measuring temperature, 
measures to reduce temperature, personal hygiene, measures to relive pain, diarrhea care, importance of follow up of anemia, and repeated investigation of stools and blood for anemia. In addition, these sessions allowed researchers follow participants' understanding and ability to adequately deal with the underlying problem, and aided participants in using all paths of assistance and make movement towards the resolution step.

Finally, researchers assessed the children and their parents' abilities to overcome the emotional stress associated with disease, e.g. anxiety, depression, school troubles, pain, relation with others, ability to manage self-care and daily duties. A score was given according their level of achievements in these assessments.

IV. Evaluation (Resolution Phase): The researchers allocated 8months for this phase, 3 months to evaluate the children's needs and ensure that the clients no longer needed professional services and had ceased dependent behavior. At this point, the therapeutic relationship ended. Researchers allocated 5 months to evaluated the effects of the model on children's health statuses, coping abilities, and ability to manage self-care using the same tools used in the assessment phase. During this period, the researchers follow the children condition by analysis of stool sample again to ensure from the absence of helminth ova and protozoan cysts under microscopic investigation. On the other hand, blood sample analysis carried out for each enrolled child to follow the results to confirm improvement of anemia.

\subsection{Content Validity}

The strength of the study tools and the booklet instruction was verified by 8 experienced, 3 professional experts from pediatric medicine department and 5 experts from pediatric nursing department, who revised the constituents for completeness. After revision by the experts, the tools were modified based on their comments.

\subsection{Pilot Study}

This was conducted to check the practicability and possibility of application, and to guess of the time wanted to fill out the questionnaire. Sixty children and their parents, representing $10 \%$ of the total study sample, were assessed. The pilot subjects were later excluded from the study sample. All necessary modifications were made based on the pilot study results.

\subsection{Administrative Design and Ethical Considerations}

Authorized consent was obtained from the principles of schools where the study was being conducted. The study aims and procedures were explained in full. Oral informed consent was gained from schoolchildren and their parents, following explanation of the study's purpose, to guarantee readiness to involve in the study. Participants were informed of their right to withdraw from the study at whatever time with no penalties on their care. The study involvements could not have had any damaging effects on applicants. Privacy of all participant information and results was ensured. Participants who tested positive for intestinal parasites and /or anemia were treated using standard drugs under medical supervision.

\subsection{Statistical Analysis}

The collected data were coded, analyzed, and tabulated, and mean, standard deviation \& chi-square tests were performed, using SPSS 20.

\section{Results}

Table 1, Illustrated that more than half of the children were in the age group 6-8 years. Concerning family sizes, more than half of the families from East Cairo (52.6\%) had only 1-2 children. By comparison, $50.9 \%$ of the families from South Cairo had $\geq 5$ children.

In East Cairo, less than one-third (29.3\%) of children's mothers were house-wives, compared with $41.0 \%$ of mothers in South Cairo (Table 2). Close to (62.0\%) of children's parents were government employees in East Cairo, whilst in South Cairo around one-third (32.7\%) were self-employed as merchants. Concerning parents' levels of education: $42.6 \%$ of mothers from East Cairo were educated to high school level, while in South Cairo $42.0 \%$ of mothers were educated to primary level only. Moreover, in East Cairo around one-third of children's fathers (32.3\%) were educated to college level or above, compared with only $11.4 \%$ in South Cairo. Regarding monthly household income of participant families, more than one-third (34.0\%) of families in East Cairo earned between 2000 to 3000 Egyptian Pounds whereas in South Cairo, $34.3 \%$ of families had a monthly income in the range of 4000-5000 Egyptian Pounds.

Table 1. Age and sex distribution of schoolchildren in East and South Cairo ( $n=600.300$ students/region)

\begin{tabular}{|c|c|c|c|c|c|c|c|c|c|c|}
\hline \multirow{3}{*}{ Age group (in years) } & \multicolumn{4}{|c|}{$\begin{array}{c}\text { East Cairo } \\
\mathbf{N}=\mathbf{3 0 0}\end{array}$} & \multicolumn{4}{|c|}{$\begin{array}{c}\text { South Cairo } \\
\mathrm{N}=300\end{array}$} & \multirow{2}{*}{\multicolumn{2}{|c|}{$\begin{array}{c}\text { Total } \\
\text { Boys \& Girls }\end{array}$}} \\
\hline & \multicolumn{2}{|c|}{ Boys } & \multicolumn{2}{|c|}{ Girls } & \multicolumn{2}{|c|}{ Boys } & \multicolumn{2}{|c|}{ Girls } & & \\
\hline & No & (\%) & No & (\%) & No & (\%) & No & (\%) & No & (\%) \\
\hline $6-8$ & 102 & $(34.0)$ & 84 & (28.0) & 88 & (29.3) & 56 & (18.7) & 330 & (55.0) \\
\hline 8-10 & 52 & (17.3) & 35 & $(11.7)$ & 64 & (21.3) & 38 & (12.7) & 189 & (31.5) \\
\hline$\geq 12$ & 17 & $(5.7)$ & 10 & $(3.3)$ & 38 & $(12.7)$ & 16 & $(5.3)$ & 81 & $(13.5)$ \\
\hline Total & 171 & $(57.0)$ & 129 & $(43.0)$ & 190 & (63.3) & 110 & (36.7) & 600 & $(100.0)$ \\
\hline \multicolumn{11}{|l|}{ Family Size } \\
\hline $1-2$ & 90 & $(52.6)$ & 66 & $(51.2)$ & 32 & (16.8) & 20 & (18.2) & 208 & (34.7) \\
\hline $2-4$ & 60 & (35.1) & 46 & (35.7) & 70 & (36.8) & 34 & (30.9) & 210 & (35.0) \\
\hline$\geq \mathbf{5}$ & 21 & (12.3) & 17 & (13.1) & 88 & (46.4) & 56 & (50.9) & 182 & (30.3) \\
\hline Total & 171 & (57.0) & 129 & (43.0) & 190 & (63.3) & 110 & (36.7) & 600 & (100.0) \\
\hline
\end{tabular}


Table 2. Distribution of parent occupations and household monthly incomes

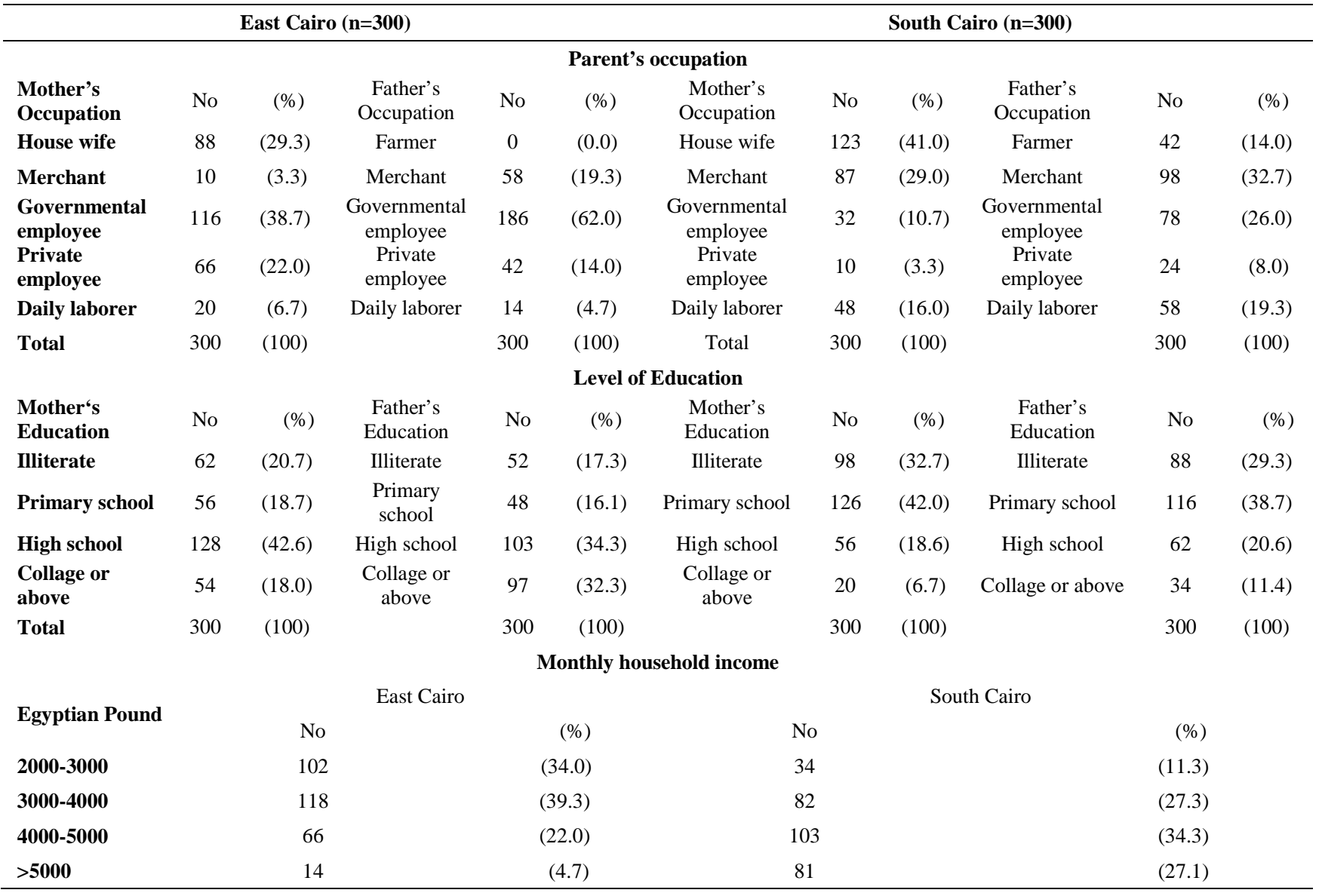

Table 3. Distribution of the most common intestinal parasites among schoolchildren.

\begin{tabular}{|c|c|c|c|c|c|c|c|c|c|c|c|c|}
\hline \multirow{3}{*}{ Intestinal Parasite } & \multicolumn{6}{|c|}{ East Cairo Age Group } & \multicolumn{6}{|c|}{ South Cairo Age Group } \\
\hline & \multicolumn{2}{|c|}{$\begin{array}{l}\text { 6-8 years } \\
(n=186)\end{array}$} & \multicolumn{2}{|c|}{$\begin{array}{c}\text { 8-10 years } \\
(\mathrm{n}=87)\end{array}$} & \multicolumn{2}{|c|}{$\begin{array}{c}\geq 12 \text { years } \\
(n=27)\end{array}$} & \multicolumn{2}{|c|}{$\begin{array}{c}\text { 6-8 years } \\
(n=144)\end{array}$} & \multicolumn{2}{|c|}{$\begin{array}{c}\text { 8-10 years } \\
(\mathrm{n}=102)\end{array}$} & \multicolumn{2}{|c|}{$\begin{array}{c}\geq 12 \text { years } \\
(\mathrm{n}=54)\end{array}$} \\
\hline & No & (\%) & No & (\%) & No & (\%) & No & (\%) & No & (\%) & No & (\%) \\
\hline Hookworm & 14 & $(7.5)$ & 5 & $(5.7)$ & 2 & $(7.4)$ & 9 & $(6.4)$ & 9 & $(8.8)$ & 3 & (5.6) \\
\hline Schistosoma mansoni & 11 & $(5.9)$ & 7 & $(8.1)$ & 0 & $(0.0)$ & 23 & (15.9) & 11 & $(10.8)$ & 4 & (7.4) \\
\hline Trichuris trichiura & 6 & $(3.2)$ & 8 & $(9.2)$ & 6 & (22.3) & 18 & (12.5) & 9 & $(8.8)$ & 6 & $(11.1)$ \\
\hline Ascaris lumbricoides & 14 & $(7.5)$ & 9 & (10.3) & 4 & $(14.8)$ & 12 & (8.34) & 8 & $(7.8)$ & 7 & $(13.0)$ \\
\hline Hymenolepis nana & 12 & $(6.5)$ & 6 & $(6.9)$ & 2 & $(7.4)$ & 8 & $(5.5)$ & 8 & $(7.8)$ & 8 & $(14.8)$ \\
\hline Enterobius vermicularis & 23 & $(12.4)$ & 10 & $(11.5)$ & 3 & $(11.1)$ & 7 & $(4.7)$ & 13 & $(12.7)$ & 5 & (9.3) \\
\hline Entamoeba histolytica & 28 & $(15.1)$ & 11 & $(12.7)$ & 1 & $(3.7)$ & 10 & $(6.9)$ & 6 & $(5.9)$ & 9 & $(16.7)$ \\
\hline Giardia lamblia & 78 & (41.9) & 31 & (35.6) & 9 & (33.3) & 57 & (39.7) & 38 & $(37.4)$ & 12 & $(22.1)$ \\
\hline
\end{tabular}

Giardia lamblia was the greatest intestinal parasite among schoolchildren in both settings (Table 3). The situation differed between the settings for the other types of intestinal parasites. In East Cairo, Entamoeba histolytica and Enterobius vermicularis constituted 15.1\% and 12.4\% of infections, respectively among schoolchildren from 6 to 8 years. Schoolchildren from 8 to10 years suffered frequently from E. histolytica (12.7\%), while Trichuris trichiura was most common (aside from $G$. lamblia) among $\geq 12$ yearold children. In South Cairo, Schistosoma mansoni and $T$. trichiura were common amongst schoolchildren from 6 to 8 years, with frequency of $15.9 \%$ and $12.5 \%$, respectively. E. vermicularis was common (12.7\%) among children aged 8-10 years, and E. histolytica and Hymenolepis nana were common among children aged $\geq 12$ years. Children were suffering from many clinical manifestations in the form of anorexia, pallor, malaise, nausea, vomiting, flatulence, diarrhea, dyspepsia, constipation, and being underweight. Chronic or recurrent abdominal pain was the most common gastroenterological complaint.

Concerning anemia, children aged 6-8 years were more vulnerable than any other age group to develop the condition (Table 4). A large majority of children in this age group from both settings were anemic (83.3\% and $87 \%$ of children from East and South Cairo, respectively). Anemia was highly prevalent among all children in both settings, with prevalence of $73.6 \%$ and $82.4 \%$ in the $8-10$ years age group. The situation was still poor for children aged $\geq 12$ years in South Cairo, where around two-thirds (64.8\%) were anemic, compared to $44.4 \%$ in East Cairo. There was a statistically significant variance amongst the two settings. 
Table 4. Distribution of anemia among schoolchildren

\begin{tabular}{|c|c|c|c|c|c|c|c|c|c|c|}
\hline \multirow{3}{*}{$\begin{array}{l}\text { Age group (in } \\
\text { years) }\end{array}$} & \multicolumn{4}{|c|}{ East Cairo } & \multicolumn{5}{|c|}{ South Cairo } & \multirow{3}{*}{$\begin{array}{c}\text { Statistical } \\
\text { analysis }\end{array}$} \\
\hline & \multicolumn{2}{|c|}{$\begin{array}{c}\text { Anemic } \\
\text { Hemoglobin }<11 \text { gldL } \\
\text { - serum iron range } \\
(40.60-122.10)\end{array}$} & \multicolumn{2}{|c|}{$\begin{array}{l}\text { Non Anemic } \\
\text { Hemoglobin> } \\
\text { 11gldL }\end{array}$} & \multirow[t]{2}{*}{$\begin{array}{l}\text { Age group } \\
\text { (in years) }\end{array}$} & \multicolumn{2}{|c|}{$\begin{array}{c}\text { Anemic } \\
\text { Hemoglobin<11gldL- } \\
\text { serum iron range (36.60- } \\
\text { 139.10) }\end{array}$} & \multicolumn{2}{|c|}{$\begin{array}{c}\text { Non Anemic } \\
\text { Hemoglobin }>11 \text { gldL }\end{array}$} & \\
\hline & No & (\%) & No & (\%) & & No & $(\%)$ & No & (\%) & \\
\hline $6-8$ y $(n=186)$ & 155 & (83.3) & 31 & (16.7) & $6-8 y(n=144)$ & 126 & (87.5) & 18 & (12.5) & - \\
\hline 8-10 y(n= 87) & 64 & (73.6) & 23 & 26.4) & $8-10 y(n=102$ & 84 & (82.4) & 18 & (17.6) & - \\
\hline$\geq 12$ y $(n=27)$ & 12 & (44.4) & 15 & (55.6) & $\geq 12$ y $(\mathrm{n}=54)$ & 35 & (64.8) & 19 & (35.2) & - \\
\hline Total & 231 & $(77.0)$ & 69 & (23.0) & & 245 & (81.7) & 55 & (18.3) & $\begin{array}{l}X^{2}=2 \\
P>0.05\end{array}$ \\
\hline Statistical & \multicolumn{2}{|c|}{$X^{2}=21.05$} & \multicolumn{2}{|c|}{$* \mathrm{P}<0.001$} & & \multicolumn{2}{|c|}{$X^{2}=13.62$} & \multicolumn{2}{|c|}{$* \mathrm{P}<0.01$} & \\
\hline
\end{tabular}

Table 5. Prevalence of malnutrition in schoolchildren

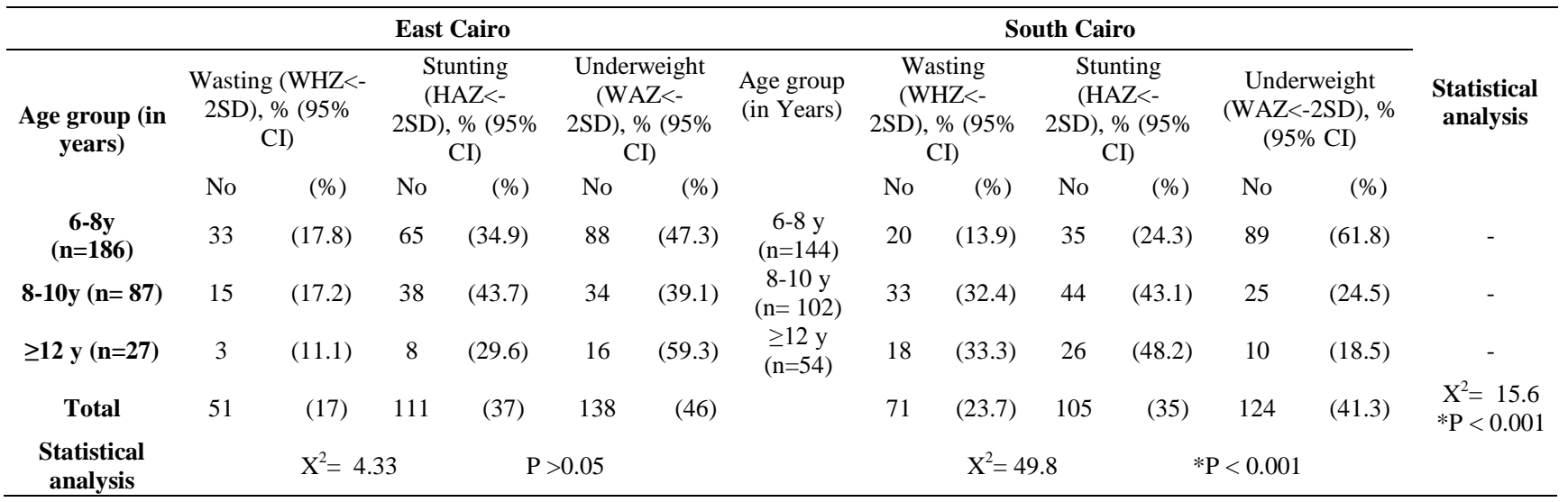

Prevalence of malnutrition in children from both settings was alarming, especially for children aged 6-8 years; $61.8 \%$ of children in this age group from South Cairo and $47.3 \%$ of those from East Cairo were underweight. The situation was also poor for children aged $\geq 12$ years. In this age group, $59.3 \%$ of children were underweight in East Cairo, compared with only 18.5\% in South Cairo (Table 5).

In East Cairo, the effects of the application of the Peplau's theory model on children in terms of knowledge of intestinal parasites and care showed statistically significant differences at all phases of the model pre/post intervention ( $\mathrm{p}>0.001$ ) (Table 6). Regarding the orientation phase of the model, only $14.0 \%$ of children and their parents scored 'Very Good' prior to the intervention, compared with $87.0 \%$ afterward. This pattern was repeated for all phases. In the resolution phase, none of the subjects obtained a 'Very Good' score preintervention, but more than two-thirds (62.7\%) achieved this post-intervention.

Table 6. Distribution of schoolchildren and parents' knowledge about intestinal parasites pre/post application of the Peplau's model in East Cairo

\begin{tabular}{|c|c|c|c|c|c|c|c|}
\hline \multirow[b]{2}{*}{$\begin{array}{l}\text { Peplau's model } \\
\text { Phases }\end{array}$} & \multicolumn{3}{|c|}{ Pre $(n=300)$} & \multicolumn{3}{|c|}{ Post $(n=300)$} & \multirow{2}{*}{$\begin{array}{l}\text { Chi-square } \\
\text { t \& p-value }\end{array}$} \\
\hline & $\begin{array}{c}\text { Poor } \\
\text { No (\%) }\end{array}$ & $\begin{array}{l}\text { Average } \\
\text { No (\%) }\end{array}$ & $\begin{array}{l}\text { V. Good } \\
\text { No (\%) }\end{array}$ & $\begin{array}{c}\text { Poor } \\
\text { No }(\%)\end{array}$ & $\begin{array}{l}\text { Average } \\
\text { No (\%) }\end{array}$ & $\begin{array}{l}\text { V. Good } \\
\text { No (\%) }\end{array}$ & \\
\hline \multicolumn{8}{|l|}{ Phase I: Orientation } \\
\hline $\begin{array}{l}\text { Parasites Types -Methods of infections - } \\
\text { Signs and symptoms }\end{array}$ & $\begin{array}{c}140 \\
(46.7)\end{array}$ & $\begin{array}{c}118 \\
(39.3)\end{array}$ & $\begin{array}{c}42 \\
(14.0)\end{array}$ & $\begin{array}{c}0 \\
(00)\end{array}$ & $\begin{array}{c}39 \\
(13.0)\end{array}$ & $\begin{array}{c}261 \\
(87.0)\end{array}$ & \multirow{4}{*}{$\mathrm{p}<0.001$} \\
\hline $\mathrm{X} \pm \mathrm{SD}$ & \multicolumn{3}{|c|}{$54.33 \pm 4.55$} & \multicolumn{3}{|c|}{$84.25 \pm 6.33$} & \\
\hline $\begin{array}{l}\text { Phase II: Identification } \\
\text { Types of investigations And Treatment }\end{array}$ & $\begin{array}{c}160 \\
(53.3)\end{array}$ & $\begin{array}{c}118 \\
(39.4)\end{array}$ & $\begin{array}{c}22 \\
(7.3)\end{array}$ & $\begin{array}{c}18 \\
(6.0)\end{array}$ & $\begin{array}{c}43 \\
(14.0)\end{array}$ & $\begin{array}{c}239 \\
(80.0)\end{array}$ & \\
\hline $\mathrm{X} \pm \mathrm{SD}$ & & $51 \pm 5.50$ & \multicolumn{4}{|c|}{$80.92 \pm 4.33$} & \\
\hline $\begin{array}{l}\text { Phase III: Exploitation: Preventions of } \\
\text { parasites }\end{array}$ & $\begin{array}{c}88 \\
(29.3)\end{array}$ & $\begin{array}{c}128 \\
(42.7)\end{array}$ & $\begin{array}{c}84 \\
(28.0)\end{array}$ & $\begin{array}{c}7 \\
(2.3)\end{array}$ & $\begin{array}{c}43 \\
(14.4)\end{array}$ & $\begin{array}{c}250 \\
(83.3)\end{array}$ & \multirow{2}{*}{$\mathrm{p}<0.001$} \\
\hline $\mathrm{X} \pm \mathrm{SD}$ & & $62.17 \pm 2.47$ & & & $75 \pm 2.33$ & & \\
\hline $\begin{array}{l}\text { Phase IV. Complications of Anemia's, } \\
\text { poor achievements }\end{array}$ & $\begin{array}{c}34 \\
(11.3)\end{array}$ & $\begin{array}{c}204 \\
(68.0)\end{array}$ & $\begin{array}{c}62 \\
(20.7)\end{array}$ & $\begin{array}{c}0 \\
(0.0)\end{array}$ & $\begin{array}{c}12 \\
(4.0)\end{array}$ & $\begin{array}{c}288 \\
(96.0)\end{array}$ & \multirow{2}{*}{$\mathrm{p}<0.001$} \\
\hline $\mathrm{X} \pm \mathrm{SD}$ & & $64.83 \pm 4.33$ & & & $.5 \pm 4.25$ & & \\
\hline $\begin{array}{l}\text { Phase V: Resolution: } \\
\text { Nursing care: Temp- - Pain relief } \\
\text { Personal care }\end{array}$ & $\begin{array}{c}188 \\
(62.7)\end{array}$ & $\begin{array}{c}112 \\
(37.3)\end{array}$ & $\begin{array}{c}0 \\
(0.0)\end{array}$ & $\begin{array}{c}64 \\
(21.3)\end{array}$ & $\begin{array}{c}48 \\
(16.0)\end{array}$ & $\begin{array}{c}188 \\
(62.7)\end{array}$ & $\mathrm{p}<0.001$ \\
\hline $\mathrm{X} \pm \mathrm{SD}$ & & $46.83 \pm 2.27$ & & & $.8 \pm 8.22$ & & \\
\hline
\end{tabular}


Table 7. Distribution of schoolchildren and parents' knowledge about intestinal parasites pre/post application of the Peplau's model in South Cairo

\begin{tabular}{|c|c|c|c|c|c|c|c|}
\hline \multirow[b]{2}{*}{$\begin{array}{l}\text { Peplau's model } \\
\text { Phases }\end{array}$} & \multicolumn{3}{|c|}{ Pre $(n=300)$} & \multicolumn{3}{|c|}{ Post $(n=300)$} & \multirow{2}{*}{$\begin{array}{l}\text { Chi-square } \\
\text { t \& p-value }\end{array}$} \\
\hline & $\begin{array}{c}\text { Poor } \\
\text { No (\%) }\end{array}$ & $\begin{array}{l}\text { Average } \\
\text { No (\%) }\end{array}$ & $\begin{array}{l}\text { V. Good } \\
\text { No (\%) }\end{array}$ & $\begin{array}{c}\text { Poor } \\
\text { No }(\%)\end{array}$ & $\begin{array}{l}\text { Average } \\
\text { No (\%) }\end{array}$ & $\begin{array}{l}\text { V. Good } \\
\text { No (\%) }\end{array}$ & \\
\hline \multicolumn{8}{|l|}{ Phase I: Orientation } \\
\hline $\begin{array}{l}\text { Parasites Types -Methods of } \\
\text { infections -Signs and symptoms }\end{array}$ & $\begin{array}{c}155 \\
(51.7)\end{array}$ & $\begin{array}{c}133 \\
(44.3)\end{array}$ & $\begin{array}{c}12 \\
(4.0)\end{array}$ & $\begin{array}{c}18 \\
(6.0)\end{array}$ & $\begin{array}{c}62 \\
(20.7)\end{array}$ & $\begin{array}{c}220 \\
(73.3)\end{array}$ & \multirow[t]{2}{*}{$\mathrm{p}<0.001$} \\
\hline $\mathrm{X} \pm \mathrm{SD}$ & & $50.58 \pm 2$ & & & $79.33 \pm 3.7$ & & \\
\hline $\begin{array}{l}\text { Phase II: Identification } \\
\text { Types of investigations and } \\
\text { Treatment }\end{array}$ & $\begin{array}{c}173 \\
(57.7)\end{array}$ & $\begin{array}{c}115 \\
(38.3)\end{array}$ & $\begin{array}{c}12 \\
(4.0)\end{array}$ & $\begin{array}{c}34 \\
(11.3)\end{array}$ & $\begin{array}{c}72 \\
(24.0)\end{array}$ & $\begin{array}{c}194 \\
(64.7)\end{array}$ & \multirow[t]{2}{*}{$\mathrm{p}<0.001$} \\
\hline $\mathrm{X} \pm \mathrm{SD}$ & & $49.08+6$. & & & $75.83 \pm 4.2$ & & \\
\hline $\begin{array}{l}\text { Phase III: Exploitation: } \\
\text { Preventions of parasites }\end{array}$ & $\begin{array}{c}102 \\
(34.0)\end{array}$ & $\begin{array}{c}152 \\
(50.7)\end{array}$ & $\begin{array}{c}46 \\
(15.3)\end{array}$ & $\begin{array}{c}32 \\
(10.7)\end{array}$ & $\begin{array}{c}57 \\
(19.0)\end{array}$ & $\begin{array}{c}211 \\
(70.3)\end{array}$ & \multirow[t]{2}{*}{$\mathrm{p}<0.001$} \\
\hline $\mathrm{X} \pm \mathrm{SD}$ & & $57.83 \pm 2$ & & & $77.42 \pm 3.8$ & & \\
\hline $\begin{array}{l}\text { Phase IV. Complications of } \\
\text { Anemia's, poor achievements }\end{array}$ & $\begin{array}{c}82 \\
(27.3)\end{array}$ & $\begin{array}{c}178 \\
(59.4)\end{array}$ & $\begin{array}{c}40 \\
(13.3)\end{array}$ & $\begin{array}{c}15 \\
(5.0)\end{array}$ & $\begin{array}{c}80 \\
(26.7)\end{array}$ & $\begin{array}{c}205 \\
(68.3)\end{array}$ & $\mathrm{p}<0.001$ \\
\hline $\begin{array}{l}\text { Phase V: Resolution: } \\
\text { Nursing care: Temp- - Pain relief } \\
\text { Personal care }\end{array}$ & $\begin{array}{c}206 \\
(68.7)\end{array}$ & $\begin{array}{c}94 \\
(31.3)\end{array}$ & $\begin{array}{c}0 \\
(0.0)\end{array}$ & $\begin{array}{c}88 \\
(29.3)\end{array}$ & $\begin{array}{c}97 \\
(32.3)\end{array}$ & $\begin{array}{c}115 \\
(38.4)\end{array}$ & \multirow[t]{2}{*}{$\mathrm{p}<0.001$} \\
\hline $\mathbf{X} \pm \mathrm{SD}$ & & $45.33 \pm 2$ & & & $65.22 \pm 3.7$ & & \\
\hline
\end{tabular}

In South Cairo, highly statistically significant differences ( $p<0.001)$ in the effects on children's knowledge of intestinal parasites and care were also seen (Table 7). Regarding the orientation phase of the model, only $4.0 \%$ of children and their parents in South Cairo obtained 'Very Good' scores pre-intervention as compared with 73.3\% post-intervention. This pattern was repeated for all phases. In the resolution phase, none of the subjects obtained a 'Very Good' score pre-intervention, whereas $38.4 \%$ achieved this post-intervention. Teachers in both study settings reported that their awareness of intestinal infection had increased.

\section{Discussion}

American Nurses Association [13] describes nursing as "the guard, upgrade, and optimization of health and abilities, hindrance of disease and damage, lessening of pain through the analysis and action of human response, and encouragement the human being”. Besides Peplau believed that nurses play a crucial role in fostering the therapeutic milieu. Peplau indicated that nurses wanted to cooperate with the patient as a "human being, with respect, empathy, and acceptance” [14].

The global burden of intestinal infestation is huge, despite significant achievements in reducing its occurrence. Nematian et al, [2] stated that schoolchildren carry the heaviest burden of intestinal parasite-associated morbidity, due to their habits of playing with or handling infested soil, eating with soiled hands, unhygienic toilet practices, and consumption of contaminated water and food.

The present study focused on investigating the prevalence of intestinal infections among primary schoolchildren in 6 schools in East and South Cairo. To investigate the effect of applying Peplau's theory, therapeutic interactions model, on schoolchildren's health status and prevention of intestinal parasite infection and anemia .Our findings demonstrate prevalence of a number of intestinal helminthes among children from the 6 primary schools studied. These results are significant for community health because intestinal parasite infection in children is associated with delayed child growth and development, poor educational achievement, reproductive health, and lack of social and economic development due to medical supervision cost.

These results are unsurprising because this is an age group where several protozoan infections predominate. Recently, Omran \& Mohammad [15] reported that parasitic infection in $74 \%$ of the studied population in Sohag governorate, Egypt. The authors highlighted that this prevalence is higher than those found in many other studies conducted in Egypt. On the other hand, Mezeid et al, [16] study in Gaza Strip, Palestine reported that prevalence of parasitic infections was higher among females $(42.7 \%)$ than among males (39.0\%) however, this result was not statistically significant $(\mathrm{p}>0.05)$.

The present study demonstrated a possible link between parental educational background and prevalence of child infection especially in South Cairo. A greater proportion of children's mothers were housewives in South Cairo than in East Cairo (41\% compared with 29\%). Concerning parental level of education, more than $40 \%$ of the mothers in East Cairo were educated to high school level, whereas in South Cairo more than $40 \%$ were educated to primary level only. Likewise, in East Cairo, more than one-third of children's fathers were educated to college level or above, compared with only $11 \%$ in South Cairo. It is clear that the cycle of infection and environmental contamination by intestinal parasites will continue unless radical steps are taken. The most common intestinal parasite that children were suffering from was Giardia lamblia.

The situation regarding other types of intestinal parasites differed between the settings and age groups. E. histolytica was common in the younger age groups from East Cairo, whilst T. trichiura was more common against children aged $\geq 12$. Results from South Cairo differed, with the most common parasites being S.mansoni for children 6-8 years, E.vermicularis for children 8-10 years, and E.hitsolytica for children $\geq 12$ years. It is likely 
that parental education plays an important role in providing children with education in healthy practices that will prevent parasitic infections.

These results concur with findings from Ramakrishnan et al, [6] in school children of Lalitpur district of Nepal.In addition, Khadka et al, [17] confirmed greater incidence of G. lamblia (13.2\%), and prevalence of $E$. histolytica $(1.7 \%)$. Great frequency of $G$. lamblia, followed by $E$. histolytica, was also noticed in Nepal. Findings of the present study designated the necessity for safety from pollution in the locality and improvement of water supply scheme. Gyawali et al [18] mentioned that Giardiasis is the most common infection through autoinfection. In the same stream [19] mentioned that school children are mainly vulnerable to parasites higher than adults.

The utmost obstacle to operative switch of parasites among people is poor information of the topographical spreading of infection and the demographic variables that stimulate the occurrence of infection. Lone et al, [20] added that schoolchildren are at high-risk for intestinal parasitic infections. The current situation of patristic infections is complex and disappointing. Intestinal parasitic infections have harmful effects on the existence, taste, growing, and development.

Parasitic intestinal infections can also adversely affect school audience and academic performance of schoolchildren [21]. The state of the variance in both settings was due to schoolchildren and families deficiency of crucial information about sanitary actions.

The present study suggests that socioeconomic status had no effect on the health status of children. The average salary in South Cairo was higher than in East Cairo. In spite of this, the health status of children from South Cairo was poorer, and children and parents' knowledge of parasitic infections and their care was worse.

Anemia in primary schoolchildren in the present study is a worrying health problem in our community because childhood anemia leads to delays in psychomotor development, and impairs cognitive performance and academic achievement. This is especially the case for children aged 6-8 years, who were more vulnerable than any other age group to develop anemia. There was an extremely statistically major variance between the two settings. The majority (83.3\%) in East Cairo and (87\%) in South Cairo were anemic. The situation was poorer for children aged $\geq 12$ years in South Cairo, where around two-thirds $(64.8 \%)$ of children were anemic, compared with $44.4 \%$ in East Cairo. Compared to facts from other governorates, results indicated that occurrence of anemia between schoolchildren in East and South Cairo governorate was relatively higher. It has been reported that in Sohag governorate $38.5 \%$ of children were infected with parasites and $52.4 \%$ of them suffered from anemia [22]. While associated with statistics from other republics, the current outcomes confirm that frequency of anemia between schoolchildren in this region of Egypt is relatively high. In rural areas of Edo state, Nigeria, prevalence of anemia remained 38.6\% among 5-6-7years schoolchildren [23].

Prevention and regulation of anemia are of vital implication. The prevalence of malnutrition in children from both settings in the present study was alarming, especially for schoolchildren between 6-8 years, where
$61.8 \%$ of children from South Cairo were underweight. In East Cairo, comparatively fewer children were underweight, although the proportion was still high at $47.3 \%$. The situation was also poor for children aged $\geq 12$ years; $59.3 \%$ of children in this age group were underweight in East Cairo, compared to only $18.5 \%$ of those from South Cairo. This condition demands an obligatory involvement program of iron supplement directed to schoolchildren. Appropriate nutrition methodologies, with food protection and modification, along with community health actions directed at parasitic control and parental care, must be established. Consistent with these findings, [24] in their study of upper Egyptian children reported that $63 \%$ of infected children and $41 \%$ of non-infected children had malnutrition.

Interestingly, the application of the model showed statistically significant effects on children from both settings in terms of knowledge of parasitic infections and their care pre/post-intervention ( $p<0.001)$. Children and parents from both settings were far more likely to obtain a 'Very Good' score at all phases after application of the intervention. The researchers found that children's hygiene practices in the resolution phase were particularly poor. None of the subjects from either setting obtained a 'Very Good' score prior to the intervention; however, the situation improved dramatically following the intervention, especially in East Cairo where $62.7 \%$ achieved a score of 'Very Good' post-intervention. The study confirmed that younger children did not know how to manage well the personal hygienic measures, and self-care.

Rice et al [25] put forward that children in young age group were unaware of hygienic practices. For example, they did not know that eating foods from a variety of sources outside of the home increased their likelihood of developing diarrhea, and that parents lacked interest in teaching the children self-reliance.

The enrolment and retention of school children knowledge for the present study is often a challenge. Penckofer et al [14] acknowledged that the Peplau theory clarified that children should collaborate with nurses and teachers to boost contribution, and to exchange information In this way, these approaches were recycled throughout the different phases (orientation, working, termination) of the nurse-participant relationship. Patients with long-lasting illness often have co-morbid despair and worry. Peplau's theory is a framework that can easily be used in caring for these patients, but can also offer a comprehensive source for guiding efficacious study.

In the present study, the knowledge levels of children, parents and teachers regarding intestinal parasites was significantly improved. This greatly helped in eliciting community interest, and the therapeutic interaction between the researchers and subjects led to increased levels of awareness regarding intestinal parasite infections and measures to solve the problem. There was evident greater improvement in schoolchildren behavior towards presentation of hygienic measures. Acka et al [26] study suggested further educational programs with communitybased interventions and endorsed that families heads from all sectors must be precisely directed to convey main health education practices to their schoolchildren and relatives. In addition to a constant reconnaissance practice focused on monitoring inactive case finding, evaluating 
the influence of health teaching communications, and adaptation to infection control patterns are crucial.

The present study investigated factors that are responsible for prevalence of intestinal parasite infections in Egypt. It was observed that children appreciated what they had learned, took their roles in disease prevention seriously. These results provide an incentive for further application of a therapeutic process in which the nurse and child respect each other as individuals, both of them learning and growing as a result of the interaction. Feedback from mothers revealed that their children had taught them to wash their hands before preparing food, keep finger nails short, and to wash vegetables and fruits before consumption.

\section{Conclusion}

Peplau's theory is considered the most famous theory explaining the interaction process between nurses and patients. Nurses engaging in pediatric care shoulder the expectations of the whole family of a sick child. The present study documents highly significant effects of the application of Peplau's theory model on child health; we conclude that children had excellent health status and complete understanding of care management following application of the model. The present study pinpoints that parasitic infections are chief community health difficulties and one of the major causes of anemia among the schoolchildren studied. Our findings call for concerted efforts to establish disease control programs in schools and implement integrated approaches based on evidencebased pediatric nursing practice.

\section{Recommendation}

The findings reported in the present study contribute to the planning of targeted integrative control strategies through universal coverage of long-lasting health education in schools together with standard measures of control. This could lead to improvements in children growth, development, and educational outcomes as well as the quality of life. Longitudinal studies are needed to decrease health damages to school age children.

\section{Acknowledgements}

We express our sincere appreciation to the head-teacher, teachers, parents and pupils of the study schools for their approval and cooperation throughout the duration of the study. My profound appreciation to Dr Ahmed Atef, Dr Nourah Alsadhan and Refah Alotabi for their kind help and great cooperation throughout the study.

\section{Disclosure}

We declare that our work was not influenced by any financial and personal relationships inappropriately.

\section{Authorship Statement}

We confirm that all listed authors meet the authorship criteria, and all authors are in agreement with the content of the manuscript.

\section{References}

[1] Hotez, P J, Savioli, L, Fenwick A. (2012). Neglected Tropical Diseases of the Middle East and North Africa: Review of Their Prevalence, Distribution, and Opportunities for Control. PLoS. Negl. Trop. Dis.6: 1475-82.

[2] Nematian J, Nematian E. Gholamrezanezhad A, Asgari AA. (2004). Prevalence of intestinal parasitic infections and their relation with socio-economic factors and hygiene habits in Tehran primary school students. Acta Tropica. 92(3): 179-186.

[3] World Health Organization (2015). Update Fact sheet $\mathrm{N}^{\circ} 115$ Schistosomiasis1van der Werf MJ1, de Vlas SJ, Brooker S, Looman CW, Nagelkerke NJ, Habbema JD, Engels D. Quantification of clinical morbidity associated with schistosome infection in sub-Saharan Africa. Acta Trop. 2003 May; 86(2-3): 125-39.

[4] Ibrahim F A.A. (2011). Prevalence and predisposing factors regarding intestinal parasitic infections among rural primary school pupils at Minia Governorate, Egypt. Journal of Public Health in Africa; volume 2: e29. pp 123-126.

[5] Pullan RL. Smith JL. Jasrasaria, R \& Brooker, SJ. (2014). Global numbers of infection and disease burden of soil transmitted helminth infections in 2010. Parasites \& vectors, 7(1), p.37.

[6] Ramakrishnan K R, Shenbagarathai A. UmaK. Kavitha R. Rajendran and P. Thirumalaikolundusubramanian P. (2007). Prevalence of intestinal parasitic infestation in HIV/AIDS patients with diarrhea in Madurai city, South India. Jpn. J. Infect. Dis., 60: 209-210. PubMed | Direct Link.

[7] WHO. (2001). 107th Session, Provisional agenda item 3.3 (EB107/31) Geneva: WHO;. Control of schistosomiasis and soiltransmitted helminthes infections. Report by the Secretariat, Executive Board.

[8] Al Ghwass MM, Halawa EF, Sabry SM, Ahmed D. Iron deficiency anemia in an Egyptian pediatric population: A crosssectional study. Ann Afr Med [serial online] 2015 [cited 2016 Feb 26]; 14: 25-31.

[9] Elalfy MS, Hamdy AM, Maksoud SS, Megeed RI. Pattern of milk feeding and family size as risk factors for iron deficiency anemia among poor Egyptian infants 6 to 24 months old. Nutr Res 2012; 32: 93-9.

[10] D'antoniop, Beeber L, Sills G and Naegle M. (2014). The future in the past: Hildegard Peplau and interpersonal relations in nursing .Nursing Inquiry; 21: 311-317.

[11] Kearney-Nunnery. (2008). Peplau's theory of interpersonal relations focuses on the nurse-patient relationship www.ukessays.com , Essays > Nursing.

[12] George B. Julia. (2012). Nursing Theories- The base for professional Nursing Practice, Introduction to nursing theoriesCurrent nursing $.3^{\text {rd }}$ ed. Norwalk, Appleton \& Lange. Current nursing.com/ nursing theory/introduction.html.

[13] American Nurses Association. (2010a). Nursing scope and standards of practice (2nd ed.). Silver Spring, MD: Author https://www.amsn.org/.../practice.../scope-and-standards/.

[14] Penckofer S, Byrn M, Mumby P, and Ferrans EC. (2013). Improving Subject Recruitment, Retention, and Participation in Research through Peplau's Theory of Interpersonal RelationsNurs Sci Q. Apr; 24(2): 146-151.

[15] Omran KH Eman \& Mohammad N Asmaa. (2015). Intestinal parasites in patients with chronic abdominal pain Journal of the Egyptian Society of Parasitology, Vol.45, No.2, August J. Egypt. Soc. Parasitol. (JESP), 45(2), 389-396.

[16] Mezeid N, Shaldoum F, Al-Hindi AI, Mohamed FS, Darwish ZE. (2014). Prevalence of intestinal parasites among the population of the Gaza Strip, Palestine. Ann Parasitol.; 60(4): 281-9. 
[17] Khadka KS, Kaphle HP, Gurung K, Manoj Sigdel M. (2013) Study of intestinal parasitosis among school going children in Pokhara, Nepal. J Health Allied Sci.; 3(1):47-50.

[18] Gyawali N, Amatya R, Nepal HP. (2009). Intestinal parasitosis in school going children of Dharan municipality, Nepal. Trop Gastroenterol. Jul-Sep; 30(3): 145-7.

[19] Cook DM, Swanson RC, Eggett DL, Booth GM. (2009). A retrospective analysis of prevalence of gastrointestinal parasites among school children in the Palajunoj Valley of Guatemala. $J$ Health Popul Nutr. Feb; 27(1): 31-40.

[20] Lone B A, Chishti M Z and Ahmad F (2011) Prevalence of Coccidia and Gastrointestinal Nematode infections in goats of Barramulla District of Kashmir Valley. Global Veterinary, 7: 27-30.

[21] Nematian J, Gholamrezanezhad A, Nematian E. (2008). Giardiasis and other intestinal parasitic infections in relation to anthropometric indicators of malnutrition: a large, population-based survey of schoolchildren in Tehran. Ann Trop Med Parasitol. Apr; 102(3): 209-14.
[22] El MasryMA. El Sahn AA,. Mahmoud MH., Eissa SM. (2002). Impacts of environmental conditions on incidence of intestinal parasitic infections in two low socioeconomic areas in Alexandria, Egypt. Bull. High Inst. Pub. Hlth. 32: 157-70.

[23] Osazuwa F, Ayo OM. (2010). Contribution of malnutrition and anaemia to anaemia status in children in rural communities in Edo state, Nigeria. North Am J Med Sci.; 2: 532-536.

[24] Yones A Doaa, Galal A Lamia, Abdallah M Alameldin , ${ }^{1}$ and Zaghlol S Khaled. (2015). Effect of enteric parasitic infection on serum trace elements and nutritional status in upper Egyptian children .Trop Parasitol. Jan-Jun; 5(1): 29-35.

[25] Rice, J.E.;Skull, S.A.; Pearce, C.; Mulholland, N.; Davie ,G. and Carapetis, J.R.(2003). Screening for intestinal parasites in recently arrived children from East Africa. J Paediatr Child Health; 39: 456-9.

[26] Acka CA, Raso G N,Goran EK, Tschannen AB, Bogoch II, Séraphin, E. Tanner, M, Obrist B. \& UtzingerJ. (2010). Parasitic worms: knowledge, attitudes, and practices in western Côte d'Ivoire with implications for integrated control. PLoS neglected tropical diseases, 4(12), p.e910. 